\title{
KEAKTIFAN SISWA DARI ASPEK SIKAP DAN KETERAMPILAN MELALUI PEMBELAJARAN AKTIF
}

\author{
Iip Siti Halifah ${ }^{1}$, Dyah Ayu Fajarianingtyas ${ }^{2}$, Nisfil Maghfiroh Meita ${ }^{3}$ \\ Program Studi Pendidikan Ilmu Pengetahuan Alam, Universitas Wiraraja ${ }^{1,2}$ \\ Program Studi Pendidikan Guru Sekolah Dasar, Universitas Wiraraja ${ }^{3}$ \\ iipsitikhalifah08@gmail.com ${ }^{1}$,azrilarka@gmail.com ${ }^{2}$, Nisfil@wiraraja.ac.id ${ }^{3}$
}

\begin{abstract}
ABSTRAK
Pembelajaran aktif adalah pembelajaran yang dapat mengaktifkan siswa dalam mencari jawaban atas pertanyaan yang di berikan guru dan juga aktif dalam mencari solusi untuk masalah yang diberikan guru. Dalam pembelajaran aktif untuk mendapatkan keaktifansiswadariaspeksikap dan keterampilan terjadi melalui proses pencarian atau percobaan. Keaktifan siswa di MTs Aqidah Usymuni dari aspek sikap, dan aspek keterampilan rendah. Salah satu solusi yang dapat diterapkan yaitu pembelajaran akif. Penelitian ini bertujuan untuk mengetahui keaktifan siswa dari aspek sikap, dan aspek keterampilan setelah diterapkan pembelajaran aktif. Jenis penelitian ini merupakan Penelitian Tindakan Kelas (PTK). Subjek penelitian adalah siswa kelas VIII yang terdiri 16 siswaperempuan.Teknik pengumpulan data berupa lembar observasi. Data keaktifan siswa dari aspek sikap, aspek keterampilan dianalisis secara deskriptif dengan persentase. Hasil penelitian yang didapatkan yaitu (1) dan pada aspek sikap indikator bertanya termasuk kategori sangat tinggi, dan indikator berpendapat termasuk kategori tinggi; (2) serta pada aspek keterampilan indikator melakukan percobaan termasuk kategori sangat tinggi, indikator menjelaskan hasil percobaan termasuk kategori sangat tinggi, dan indikator merefleksi termasuk ketegori sangat tinggi. Pembelajaran Aktif dapat mengetahui keaktifan siswa dari aspek sikap, dan keterampilan.
\end{abstract}

Kata kunci: Pembelajaran aktif, Keaktifan siswa.

\begin{abstract}
Active learning is learning that can activate students in finding answers to questions given by the teacher and also active in finding solutions to problems given by the teacher. In active learning to gain knowledge, attitudes and skills occur through a search or trial process. The activeness of students in MTs Aqidah Usymuni from aspects of knowledge, aspects of attitude, and skills aspects is low. One solution that can be applied is akif learning. This study aims to determine the learning and activeness of students from aspects of knowledge, aspects of attitudes, and aspects of skills after active learning is applied. This type of research is Classroom Action Research (CAR). Research subjects were eighth grade students consisting of 16 female students. Data collection techniques in the form of observation sheets. Student activity data from the aspect of attitude, aspects of skills were analyzed descriptively by percentage. The research results obtained are (1) and the attitude aspects of the indicators ask include very high categories, and the indicators of opinion are included in the high category; (2) as well as on the skill aspects of the indicators conducting experiments including very high categories, indicators explaining experimental results are very high categories, and indicators reflect including very high categories. Active Learning can find out students' activeness from aspects of attitude, and skills.
\end{abstract}

Keywords: Active learning, student activity. 


\section{PENDAHULUAN}

(Silberman,2014) menjelaskan bahwa "pendidikan bertujuan untuk mendapatkan pengetahuan, sikap dan keterampilan. Pembelajaran kognitif (pengetahuan) mencakup pemerolehan informasi dan konsep. Pembelajaran perilaku (keterampilan) mencakup pengembangan kompotensi pada kemampuan siswa dalam mengerjakan tugas. Pembelajaran afektif (sikap) meliputi peninjauan dan penjelasan tentang perasaan". Jadi pendidikan merupakan usaha sadar yang bertujuan untuk mengembangkan potensi diri yang dimiliki siswa untuk mendapatkan beberapa hal diataranya yaitu: kecerdasan, keterampilan yang dimiliki siswa dan memiliki rasa tanggujawab sehingga untuk mendapatkan beberapa hal tersebut maka perlu adanya proses penemuan dengan tujuan untuk mengembangkan potensi yang dimiliki siswa. Mata pelajaran yang mengajarkan mengenai suatu proses penemuan adalah Ilmu Pengetahuan Alam (IPA). Pelajaran IPA dapat dijadikan suatu wahana bagi siswa untuk mempelajari alam sekitar secara sistematis sehingga siswa bukan hanya menguasai kumpulan pengetahuan yang berupa fakta-fakta, konsep-konsep, atau prinsip-prinsip saja tetapi juga merupakan suatu proses penemuan.

IPA merupakan ilmu yang berkaitan dengan cara mencari tahu alam secara sistematis, sehingga IPA bukan hanya penguasaan kumpulan pengetahuan yang berupa fakta-fakta, konsep-konsep, atau prinsip-prinsip saja tetapi juga merupakan suatu proses penemuan. Proses pembelajaran IPA lebih menekankan pada pemberian pengalaman langsung untuk mengembangkan potensi siswa agar dapat menjelajahi alam dan memahami alam sekitar secara ilmiah, sehingga siswa akan lebih aktif karna siswa dapat berinteraksi dengan siswa yang lain maupun dengan alam sekitar melalui kesibukan yang dilakukan selama mengikuti pembelajaran. Aktivitas yang dilakukan siswa selama mengikuti pembelajaran dapat meningkatkan keaktifan siswa(Habibi, 2010).

Berdasarkan hasil wawancara yang telah dilakukan pada guru IPA MTs Aqidah Usymuni pada tanggal 12 januari 2018 menyatakan bahwa siswa yang tidak aktif ditinjau dari aspek sikap (12 siswa); aspek keterampilan (11 siswa). Model yang digunakan oleh guru MTs Aqidah Usymuni yaitu model konfesional yang mana lebih banyak guru yang berperan aktif dibandingkan siswa, sehingga pembelajaran terkesan membosankan. Berdasarkan hasil obesrvasi dan wawancara Salah satu alternatif yang dapat mengaktifkan siswa dari aspek sikap dan keterampilan Guru harus menerapkan model pembelajaran yang melibatkan siswa aktif. Sehingga peneliti tertarik untuk menerapkan model pembelajaran tersebut.

(Hariyanto dan warsono, 2012) menjabarkan tentang pembelajaran aktif adalah istilah model pembelajaran yang lebih berpusat pada siswa untuk belajar secara mandiri. Pembelajaran aktif bertujuan untuk mengoptimalkan semua potensi yang dimiliki siswa sehingga mencapai hasil secara maksimal sesuai karakteristik yang dimiliki siswa, (Aziz and kholis, 21014)

\section{METODE PENELITIAN}

Penelitian ini menggunakan penelitian tindakan kelas. Rancangan pada penelitian ini diambil dari penelitian Kemmis \& Mc Taggart yang terdiri dari 2 siklus, setiap siklus terdiri dari empat tahap, Tahap perencanaan, pelaksanaan, pengamatan dan refleksi. penelitian ini dilakukkan untuk mengetahui keaktifan siswa dari aspek sikap dan keterampilan.

Subjek penelitian ini yaitu siswa kelas VIII MTs Aqidah Usymuni Tarate, Kecamatan Pandian, Kabupaten Sumenep yang berjumlah 16 siswa.Metode pengumpulan data yang digunakan yaitu wawancara dilakukan kepada guru IPA, penyebaran angket kepada siswa, penyebaran soal prestest dan postest. serta 
mengamati siswa melalui lembar observasi sikap dan keterampilan.

\section{HASIL}

Variabel yang diamati pada siklus 1 dan siklus 2 pada saat pembelajaran berlansung yaitu keaktifan siswa dari aspek sikap dan keterampilan Berikut data hasil keaktifan siswa dari aspek sikap pada siklus 1 dapat dilihat pada gambar 1 berikut.

Gambar 1data hasil keaktifan siswa dari aspek sikap siklus 1 .

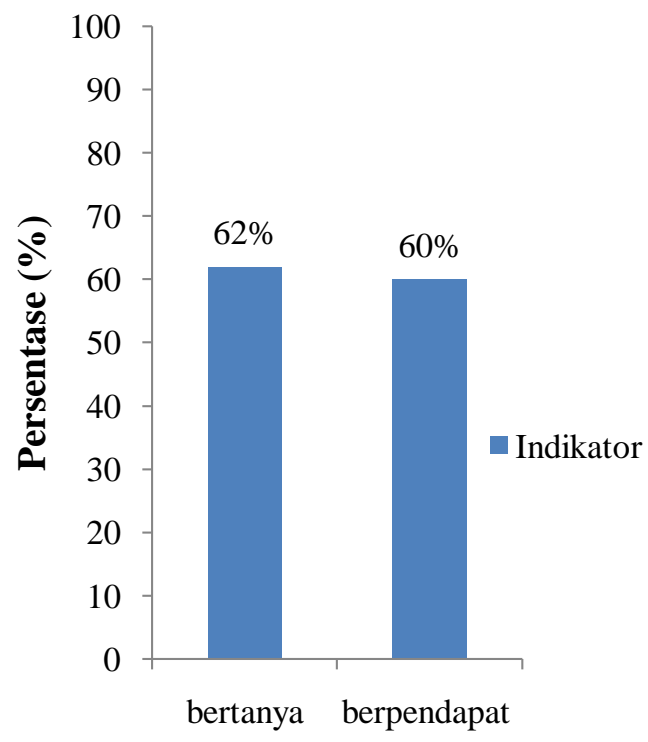

Data hasil keaktifan siswa dari aspek sikap siklus 2 dapat dilihat pada gambar 2 . Gambar 2 keaktifan siswa dari aspek sikap

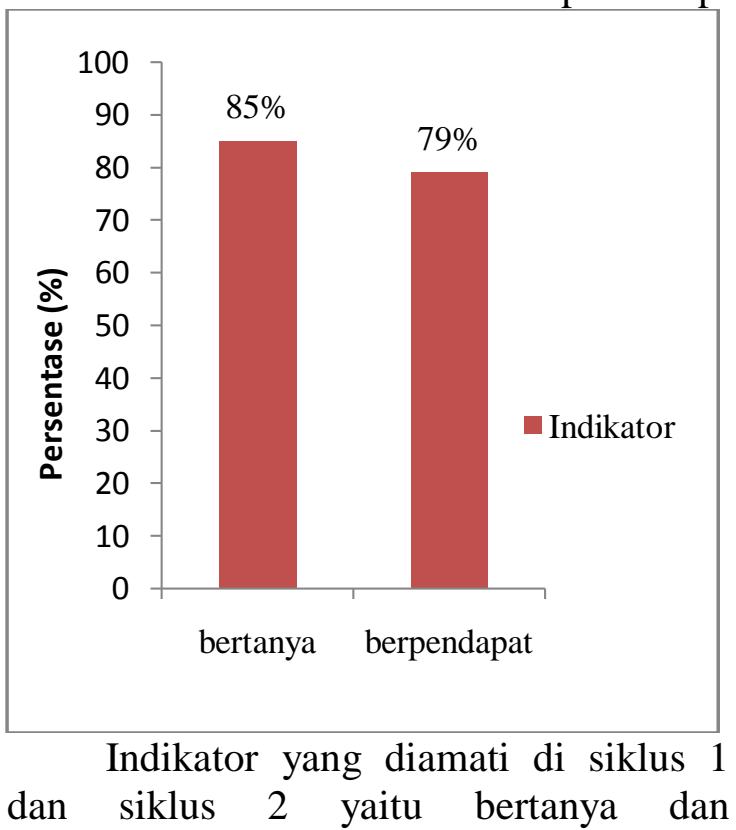

berpendapat. Hasil rata-rata nilai keaktifan siswa dari aspek sikap di siklus 1 indikator tertinggi yaitu indicator bertanya sebesar $62 \%$ sedangkan keaktifan siswa dari aspek sikap pada siklus 2 indikator bertanya sebesar $85 \%$ dengan kategori sangat tinggi

Data hasil keaktifan siswa dari aspek keterampilan siklus 1 dapat dilihat pada gambar 3.

Gambar 3 keaktifan siswa dari aspek keterampilan.

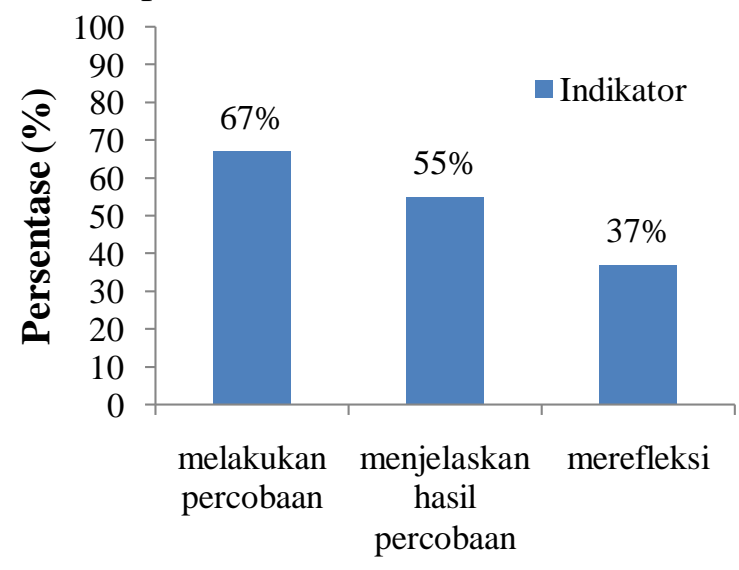

Data hasil keaktifan siswa dari aspek keterampilan siklus 2 dapat dilihat pada gambar 4.

Gambar 4 keaktifan siswa dari aspek keterampilan.

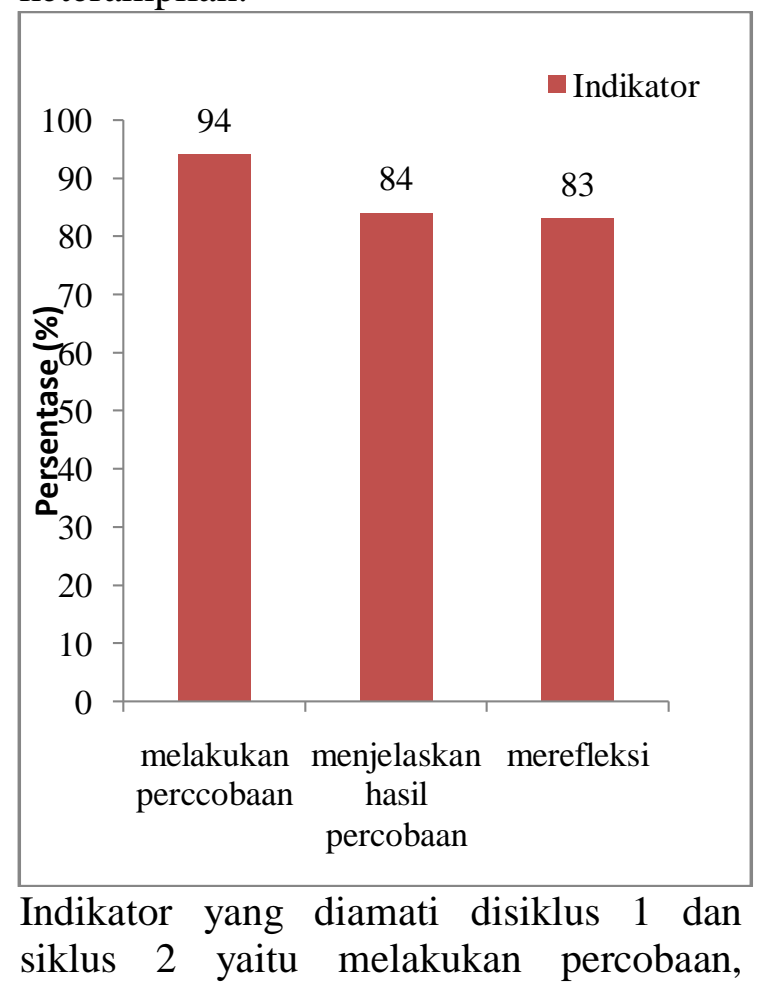


menjelaskan hasil percobaan, dan merefleksi. Hasil nilai rata-rata keaktifan siswa dari aspek keterampilan di siklus 1 indikator tertinggi yaitu melakukan percobaan sebesar $67 \%$, sedangkan pada siklus 2 indikator tertinggi yaitu melakukan percobaan sebasar $94 \%$.

\section{PEMBAHASAN}

1. Keaktifan siswa dari aspek sikap

Pada siklus 2 dalam pembelajaran aktif tahap 4 dan 5 lebih berpusat pada siswa, yang mana guru meminta semua siswa untuk bertanya mengenai materi yang tidak dipahami, aspek penting yang harus diperhatikan guru dalam pelaksanaan pembelajaran IPA adalah melibatkan siswa secara aktif dalam pembelajaran untuk mengembangkan kemapuan berpikirnya. Memberikan kesempatan kepada siswa untuk bertanya. Dengan bertanya maka siswa akan berlatih mengemukakan gagasan dan respon terhadap permasalahan yang dihadapinya sehingga dapat mengembangkan pengetahuan IPA.

Pada siklus 2 ini siswa sudah mulai berani dalam bertanya karena mereka banyak berinteraksi dengan teman sebayanya. Sesuai dengan teori Vygotsky yang menyatakan bahwa siswa sebaiknya belajar melalui interaksi dengan orang dewasa dan teman sebaya yang lebih mampu. Interaksi sosial ini memacu terbentuknya ide baru dan memperkaya perkembagan intelekstual siswa (Cahyo, 2012).

2. Keaktifan siswa dari aspek keterampilan.

Pada sikus 1 ini keaktifan siswa dari aspek keterampilan tidak mencapai kriteria keberhasilan. Hal ini dikarenakan pada siklus 1 ada beberapa siswa tidak ikut serta saat melakukan percobaan karena sebelumnya guru tidak perna melakukan percobaan pada saat mengajar, dan juga waktu tidak mencukupi sehingga hanya beberapa siswa saja yang aktif. Keaktifan siswa dari aspek keterampilan pada siklus 2 indikator tertinggi yaitu melakukan percobaan sebesar 94\%, dengan melakukan percobaan siswa akan terampil karena siswa mengamati secara langsung mengenai apa yang telah dipelajari melalui percobaan.

Pembelajaan IPA berkaitan dengan cara mencari tahu dan memahami alam seecara sistematis, sehingga belajar IPA merupakan suatu proses penemuan, jika siswa tidak terbiasa mencoba menemukan sendiri pengetahuan atau informasi yang sedang dipelajari maka pelajaran yang diperoleh tidak bermakna dan akan dapat terlupakan. Aspek pokok dalam pembelajaran IPA adalah anak dapat menyadari keterbatasan pengetahuan mereka, memiliki rasa ingin tahu untuk menggali berbagai pengetahuan baru melalui percobaan dan akhirnya dapat diaplikasikan dalam kehidupan sehari-hari (Maulidar, 2013) Menurut piaget anak SMP berada pada tahap formal operational (11-15) yaitu termasuk kedalam usia anak remaja yang berfikir dengan cara yang lebih abstrak dan logis, sehingga mereka mampu memecahkan suatu masalah yang diberikan oleh guru dan juga mampu berfikir secara sistematik (Cahyo, 2012). Pada siklus ke 2 ini dapat dikatakan tuntas karena persentase $>81 \%$. Maka penelitian di hentikan sampai siklus 2 karna sudah mencapai kriteria keberhasilan.

Pada siklus 2 dalam pembelajaran aktif tahap 3 dan 5 siswa terlihat aktif dan antusias dalam melakukan percobaan. Serta terampil dalam berkomunikasi diantaranya yaitu terampil dalam menyampaikan hasil percobaan materi tekanan maupun menyampaikan pendapatnya. Sesuai denganpenelitian (Raehang, 2014), bahwa pembelajaran aktif sebagai induk pembelajaran kooperatif dapat menigkatkan keaktifan siswa, sehingga memperoleh pengetahuan, kecakapan baik melalui mendengar, mengamati serta terjadi keterbukaan dan saling bekerjasama dalam memecahkan suatu masalah. 


\section{KESIMPULAN}

Berdasarkan hasil pembahan dalam penelitian ini dapat disimpulkan sebagai bahwakeaktifan siswa dari aspek sikap melalui pembelajaran aktif indikator bertanya termasuk kategori sangat tinggi, dan indikator berpendapat termasuk kategori tinggi. Dan keaktifan siswa dari aspek keterampilan melalui pembelajaran aktif indikator melakukan percobaan termasuk kategori sangat tinggi, indikator menjelaskan hasil percobaan termasuk kategori sangat tinggi, dan indikator merefleksi termasuk ketegori sangat tinggi.

\section{SARAN}

1. Pada saat guru mengajar sebaiknya siswa diberi lembar penilaian keterlaksanaan pembelajaran pada saat pembelajaran berlangsung.

2. Dalam membuat soal sebaiknya diperbanyak sehingga semua soal dapat memuat materi.

\section{DAPUS}

Cahyo, A. N. (2012). Panduan aplikasi teori-teori belajar mengajar teraktual dan terpopuler. Yogyakarta: Diva press.

Aziz,A.and Kholis, N. (2014) 'pengembangan perangkat pembelajaran aktif (Actie Learning) dengan strategi synergetic Teaching pada mata diklat mengukur besaranbesaran listrik dalam rangkaian elektronika kelas X di SMK Sunan drajat lamongan; jurnal pendidikan teknik elektro,03(02), pp.83-88. aailable at: http://jurnalmahasiswa.unesa.ac.id/in dex.php/jurnal-pendidikan-teknikelektro,articel/iew/7890.

Habibi. (2010). Pembelajaran IPA 1. Sumenep: Unija press.

Hariyanto dan warsono (2012) 'pembelajaran aktif', in. Bandung: PT Remaja Rosdakarya.

Maulidar, W. O. Dan. (2013). Penggunaan metode eksperimen pada pembelajaran materi sifat bahan dan kegunaannya terhadap hasil dan respon belajar siswa kelas iv min tungkob aceh besar. Jurnal Ilmiah didaktika Februari, XIII(2), 336-350. Retrieved from https://jurnal.arraniry.ac.id/index.php/didaktika/articl e/view/482/400

Raehang. (2014). Pembelajaran aktif sebagai induk pembelajaran koomperatif. Jurnal Al-Ta'dib, 7(1), 149-167. Retrieved from http://ejournal.iainkendari.ac.id/altadib/articel/view/249/239.

Silberman, M. (2014). Active learning: 101 cara belajar siswa aktif. Bandung: nuansa cendekia. 